\title{
History of 232-F, Tritium Extraction Processing (U)
}

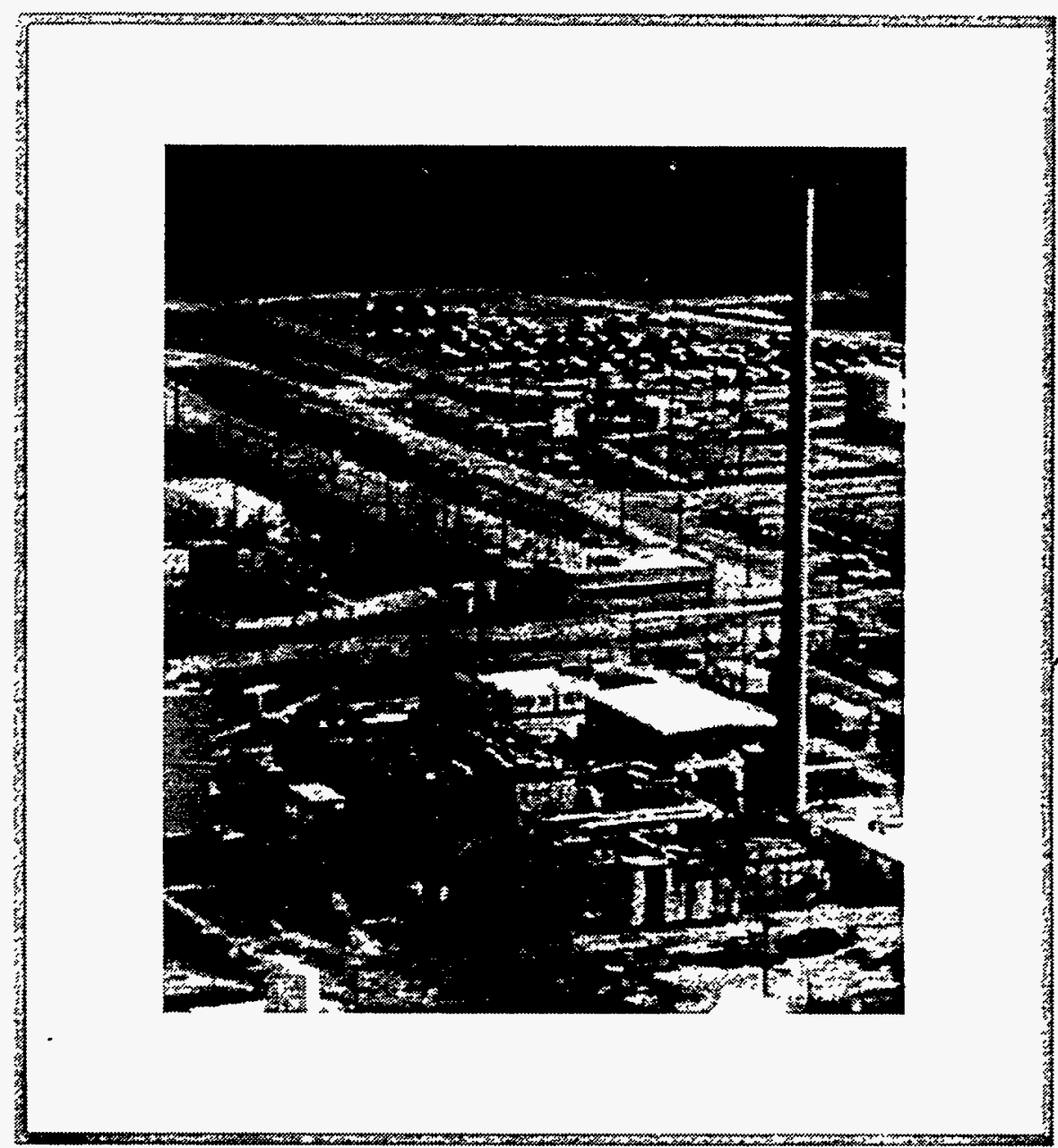

Solid Waste and Environmental Restoration Division

Transition, Decontamination and Decommissioning Department

Westinghouse Savannah River Company

Savannah River Site

Aiken, SC 29803

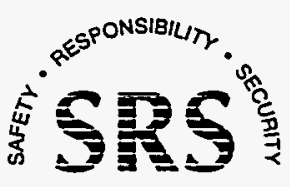

PREPARED FOR THE U. S. DEPARTMENT OF ENERGY UNDER CONTRACT NO. DE-AC09-89SR18035 DISTRIBUTION OF THIS DOCUMENT IS UNLIMITED 


\section{DISCLAIMER}

This report was prepared as an account of work sponsored by an agency of the United States Government. Neither the United States Government nor any agency thereof, nor any of their employees, make any warranty, express or implied, or assumes any legal liability or responsibility for the accuracy, completeness, or usefulness of any information, apparatus, product, or process disclosed, or represents that its use would not infringe privately owned rights. Reference herein to any specific commercial product, process, or service by trade name, trademark, manufacturer, or otherwise does not necessarily constitute or imply its endorsement, recommendation, or favoring by the United States Government or any agency thereof. The views and opinions of authors expressed herein do not necessarily state or reflect those of the United States Government or any agency thereof. 


\section{DISCLAIMER}

Portions of this document may be illegible in electronic image products. Images are produced from the best available original document. 
WSRC-IM- 94-39

August, 1994

\title{
HISTORY OF 232-F,
}

\section{TRITIUM EXTRACTION PROCESSING}

(U)

\author{
by: \\ George W. Blackburn
}

Approved By:

Dennis A. Stevenson

Solid Waste and Environmental Restoration Division Transition, Decontamination and Decommissioning Department

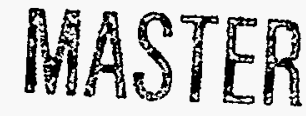

DISTRIBUTION OF THIS DOCUMENT IS UNLIMITED 
TABLE OF CONTENTS

PAGE NOS.

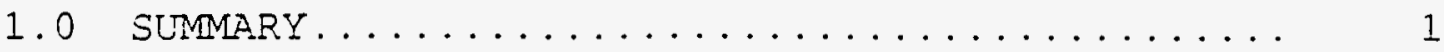

2.0 FACILITY AND PROCESS HISTORY $-232-F \ldots \ldots \ldots \ldots 2$

3.0 LESSONS LEARNED .................... 6

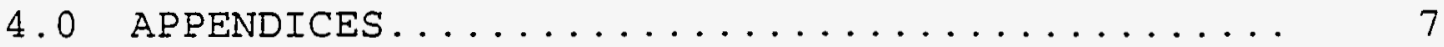

Appendix A Flow Sheet

Facility Footprint

Appendix B Photo of 232-F Building Facing North

Photo of 232-F Building Facing South

Photo of $232-\mathrm{F}$ Building Facing West

Photo of 232-F Stack South Side

Photo of 232-E Process Control Room

Photo of 232-E Corridor

Photo of 232-F Process Cabinet Basement

Photo of 232-F Mechanical Equipment Room

Photo of 232-F Kanne Monitoring Room

Photo of 232-F Material Handling Room

Photo of 232-F Process Cabinet as Viewed from the Control Room

Photo of 232-F Laboratory 


\subsection{SUMMARY}

In 1350 the Atomic Energy Comnission authorized the Savannan River Project principally for the production of tritium and plutonium-239 for use in thermonuclear weapons. 232-F was built as an interim facility in 1953 - 1954, at a cost of $\$ 3.9 \mathrm{M}$. Tritium extraction operations began in October, 1955, after the reactor and separations startups.

In July 1957 a larger tritium facility began operation in 232-H. In 1958 the capacity of $232-\mathrm{H}$ was doubled. Also, in 1957 a new task was assigned to Savannah River - the loading of tritium into "reservoirs" that would be actual components of thermonuclear weapons. This was the closest Savannah River ever came to justifying the name widely applied to the plant by the local population, "The Bomb Plant". 
The facility covers $19,250 \mathrm{Et}^{2}$ with $17,000 \mathrm{ft}^{2}$ enclosed. The building consists of two abutting sections, a process wing and a laboratory/administrative wing. The process wing is 128 feet by 78 feet while the laboratory/administrative wirg is 98 feet by 70 feet. The building frame is of structurai steel with exterior walls of Transiteß. All floors are poured concrete with tile in the laboratory/administrative areas. Interior walls are Transite $\mathbb{B}$ except where radiation levels required concrete, steel and lead as shielding materials. The floors and walks in process areas are coated with Amercoat $($. The roof is constructed of cement slab with tar mopped on saturated tar felt and covered with gravel.

The building is a one-story structure except in the center where a second story and basement were required to house sections of the process lines. Roof areas were utilized in the placement of ventilation equipment. Ductwork from the roof leads to a concrete fan platform on the southside of the main building. The fans are connected to a reinforced concrete stack 200 feet tall 10 feet diameter at base - 5 feet at chimney cap. (Floor plan attached.) The air intake ducts are galvanized sheet and the exhaust ducts are stainless steel. The heating and ventilation supply ducts are insulated with bitumen coatings.

Tritium processing did not require a class 1 structure in that time frame, so structural steel, cement slabs and Transite $\mathbb{R}$ walls were used as the norm. Other building materials used (later defined as hazardous) were asbestos insulation, asbestos floor tiles, lead-based paints and lead brick used for personnel radiation shielding. The process used mercury in Sprengel $®$ pumps and diffusion pumps. The Sprengel® pumps also contained some Inconel® parts.

The world political climate played a significant part in the design, construction and operation of the plant. The korean military action was in full swing during construction design and later the cold war with USSR would continue at an accelerated pace. Before the Korean armistice was signed, Red China had committed troops to assist the North Korean Army. World peace appeared to be an elusive dream.

All of these factors limited alternate process studies and created a national urgency and demand to place nuclear weapons in the U. S. arsenal as soon as possible. Construction schedules were ambiguous at best, however, the working crews were aware of the national need and through patriotism developed an esprit de corps to succeed that may never be equaled. 
2.0 FACILITY AND PROCESS HISTORY - 232-E - (Contd)

Process equipment and designs were drawn from experience at the Hanford Works and tritium process flows were extrapolated from the initial tritium production conducted at the Los Alamos Scientific Laboratory.

The 232-F process equipment was enclosed in a stainless steel cabinet (sometimes called hood) with panels. The panels were Eramed and held glass windows for visual inspection of equipment. The panels were mounted on tracts to permit opening for access to equipment for maintenance or replacement. This early design of "by guess and by gosh" proved to be ineffective in containing contamination within the cabinet. Soon after start-up, contamination problems were evident within the process room, sometimes spreading to other adjacent rooms. Frequent decontamination efforts were necessary by the tritium operators. This contamination/decontamination cycle sometimes resulted in harsh words between the mechanics and operators. The mechanics were not qualified to decontaminate, yet they were the main cause of contamination releases within the process room while doing their work. Most contamination releases occurred when the mechanics withdrew their hands/arms from within the cabinet after working on process equipment that was contaminated. The contaminated particles fell to the floor and were spread with either air movement or the individuals feet. A gradual contamination control improvement evolved from these experiences. First absorbent paper was placed on the floor around the work area. Then plastic was used in a larger floor area. Finally, plastic huts were built to completely isolate the worker from the rest of the process room. This method proved to be the most effective way to control the spread of contamination and is used widely throughout the industry today. Some of the operators had carpenter experience and were the best hut builders. In some cases the hut builder would sign his name with a flow master pen on the hut door acknowledgment of his pride in hut building. With better control of contamination a much improved relationship developed among the workers. Teamwork became a reality. 
2.0 FACILITY AND PROCESS HISTORY - 232-F - (Contd)

The contamination problem though improved was never completely resolved, but nevertheless did not hinder the desire for operators to be assigned to the facility. In those days, few facilitjes were air conditiored. $232-F$ was air conditioned, not necessarily for creature comfort, but the facilicy instrumentation reliability required a conscanc temperature. The operators nicknamed the facility, "the country club", "which would later follow over to the H Area tritium facilities. It is interesting to note that a number of people assigned to the facility would later serve as department heads and one advancing to nuclear materials processing director with the Savannah River Plant manager reporting to him.

Production goals were met or exceeded during the $232-\mathrm{F}$ operating time period. The irradiated targets were received as canned "slugs" about 12 inches in length and 2 inches in diameter. The slugs were removed from the shipping cask remotely. Using a manipulator, the aluminum sheeting or hull was separated from the Li-Al target (called decanning) through a die. The hull was crushed to conserve space and placed in the can the slug was shipped in.

Numerous hulls were accumulated until the container was full. It was then shipped to the burial ground. The target was placed in a crucible and charged to one of the two extraction furnaces. The furnace was placed under a vacuum and heated in excess of the target-melting point. Tritium, helium and small concentrations of ordinary hydrogen were extracted from the target during the diffusion heat cycle. Also, some fission products were entrained in the flows. A diffusion pump delivered the gases through a palladium metal barrier where the heavier tritium was extracted from the bottom and captured in a hold tank for analysis. The by-product line containing $\mathrm{He} 3, \mathrm{He} 4, \mathrm{~N}_{2}$ and trace $\mathrm{T}_{2}$ was pumped to storage tanks for analysis and later pumped through a zeolite bed to a cylinder trailer for shipment to Oak Ridge, Tennessee or Mound Laboratory, Miamisburg, Ohio. The by-product was released at separate locations to prevent a single sourse release of $\mathrm{He} 3$ that could be detected by an adversary. (He3 amounts could be used to back calculate tritium production rates. These numbers were extremely sensitive during that time frame.)

The tritium "goodie" stream, was pumped through the thermal diffusion column where the pure tritium was extracted, captured in a hold tank, sampled to await product containers loading in a 12 liter LP, later 50 liter LP shipping cylinder. (The LP stood for low pressure.) The loaded container was stored in the Kanne (pronounced Kanee) room where it was individually monitored for leaks. The cylinders 
were released to DOE (called Atomic Energy Commission then) couriers for van vehicle transportation to Mound Laboratory, Miamisburg, Ohio. 
2.0 FACILITY AND PROCESS HISTORY - 232-F - (Contd)

The off gas from the top of the column contained $\mathrm{H}_{2}, \mathrm{D}_{2}$, fission products and traces of tritiurn. This off gas was captured in a tank, sampled and awaited analysis before being released to the stack.

One of the shortcomings of the process was the column efficiency. The tritium capture was never absolute. Acceptable during that time frame, but unacceptable in today's climate. The process also lacked recycle capabilities.

Maintenance problems experienced were usually leaking seals on the Sprengel ${ }^{\circledR}$ pumps. A replacement Edwards ${ }^{\circledR}$ pumps was placed in service in 1958 and proved to be an improvement.

The furnaces were heated by numerous Calrod® elements and each furnace required element replacement each year of operation.

During 1953-1954, as the results of weapons tests were evaluated, Savannah River Plant experienced great shifts in the forecast of demands for tritium and plutonium. This in turn, caused great swings in demand for Iithium-aluminum target elements. The $232-\mathrm{F}$ facility had low capacity throughput of only one slug per furnace per cycle. This was not nearly enough to meet the demand. The 232-H Tritium Facility extraction furnaces were modified to accommodace long tubes. These new assemblies were full-length, extending from top to bottom of the reactor. During the extraction process, the throughput went from extracting tritium from one 12 inch irradiated slug to a 12 foot irradiated tube per furnace.

Tritium continued to be separated and purified in both $232-\mathrm{F}$ and 232-H until August of 1958 when a new, higher capacity separations line in $232-\mathrm{H}$ went into service. In october, the F-Area Tritium Facility was shutdown permanently. A shutdown procedure was approved to remove all residual tritium and Elush process lines and equipment with an inert gas. All service to the building was shutdown and the building locked. Custodianship has been held by the Separations Department personnel through the years with no budget for upkeep of equipment and/or building. In some cases, needed equipment, such as the emergency diesel generator has been scavenged for use elsewhere on plant. 


\subsection{LESSONS LEARNED}

As with any new processing facility, numerous design flaws were evident. Operators and mechanics pointed out a need for better ergonomics in future processing facilities. These suggestions were an important resource to the engineering of $232-\mathrm{H}$ and $234-\mathrm{H}$.

Contamination control was much improved during the $232-\mathrm{F}$ operation as previously stated. Tritium is unique in handling and containment. Any organic material containing hydrogen would not adequately isolate tritium over a period of time. The bonding of the hydrogen atoms of organic material was not sufficient to prevent swapping of tritium atoms. It was learned that normal plastic hoods, suits, needed to be thicker to provide better worker protection. Time exposures were given, not necessary for radiation exposure, but rather to limit the time the worker would be exposed to this atom exchange and prevent tritium assimilations.

The original thinking was the necessity of close vertical tolerance of the thermal diffusion column. Great pains went into the fabrication of the column at General Research, Cambridge, Massachusetts. A huge concrete reinforced beam was fabricated and shipped with the column as support to prevent vibration and/or column warpage. The same arrangement was made in installing the column in 232-F. Much later it was learned the column performed successfully at a much larger operating envelope than previously thought. This information was used in the design of $232-\mathrm{H}$. The loaded LP containers were monitored in the Kanne room. Originally, a chamber was installed to monitor each individual shipping LP container. It was later determined that a manifold to one chamber was sufficient to provide leak detection protection.

All-in-all, the $232-F$ processing facility was quite successful in providing the tritium necessary for the initial arms race. Dedication was unparalleled by all those people assigned. Constant improvement of equipment, process capabilities and safety were documented through the years and were recently incorporated in the design and building of the recently completed Replacement Tritium Facilities (RTF). 
4.0 APPENDICES

$\begin{array}{ll}\text { Appendix A } & \begin{array}{l}\text { Flow Sheet } \\ \text { Facility Footprint }\end{array} \\ \text { A.ppendix B } & \text { Photo of } 232-\mathrm{F} \text { Building Facing North } \\ & \text { Photo of } 232-\mathrm{F} \text { Building Facing South } \\ & \text { Photo of } 232-\mathrm{F} \text { Building Facing west } \\ & \text { Photo of } 232-\mathrm{F} \text { Stack South Side } \\ & \text { Photo of } 232-\mathrm{F} \text { Process Control Room } \\ & \text { Photo of } 232-\mathrm{F} \text { Corridor } \\ & \text { Photo of } 232-\mathrm{F} \text { Process Cabinet Basement } \\ & \text { Photo of } 232-\mathrm{F} \text { Mechanical Equipment Room } \\ & \text { Photo of } 232-\mathrm{F} \text { Kanne Monitoring Room } \\ & \text { Photo of } 232-\mathrm{F} \text { Material Handling Room } \\ & \text { Photo of } 232-\mathrm{F} \text { Process Cabinet as Viewed } \\ & \text { from the Control Room } \\ & \text { Photo of } 232-\mathrm{F} \text { Laboratory }\end{array}$




\section{APQENDIX A}

- FLOW SHEET

- FACILITY FOOTPRINT 


\section{APPENDIX B}

- PHOTO OF 232-F BUILDING FACING NORTH

- PHOTO OF 232-F BUILDING FACING SOUTH

- PHOTO OF 232-F BUILDING FACING WEST

- PHOTO OF 232-E STACK SOUTH SIDE

- PHOTO OF 232-F PROCESS CONTROL ROOM

- PHOTO OF 232-F CORRIDOR

- PHOTO OF 232-F PROCESS CABINET BASEMENT

- PHOTO OF 232-F MECHANICAI EQUIPMENT ROOM

- PHOTO OF 232-F RANNE MONITORING ROOM

- PHOTO OF 232-F MATERIAL HANDLING ROOM

- PHOTO OF 232-F PROCESS CABINET AS VIEWED FROM THE CONTROL ROOM

- PHOTO OF 232-F LABORATORY 


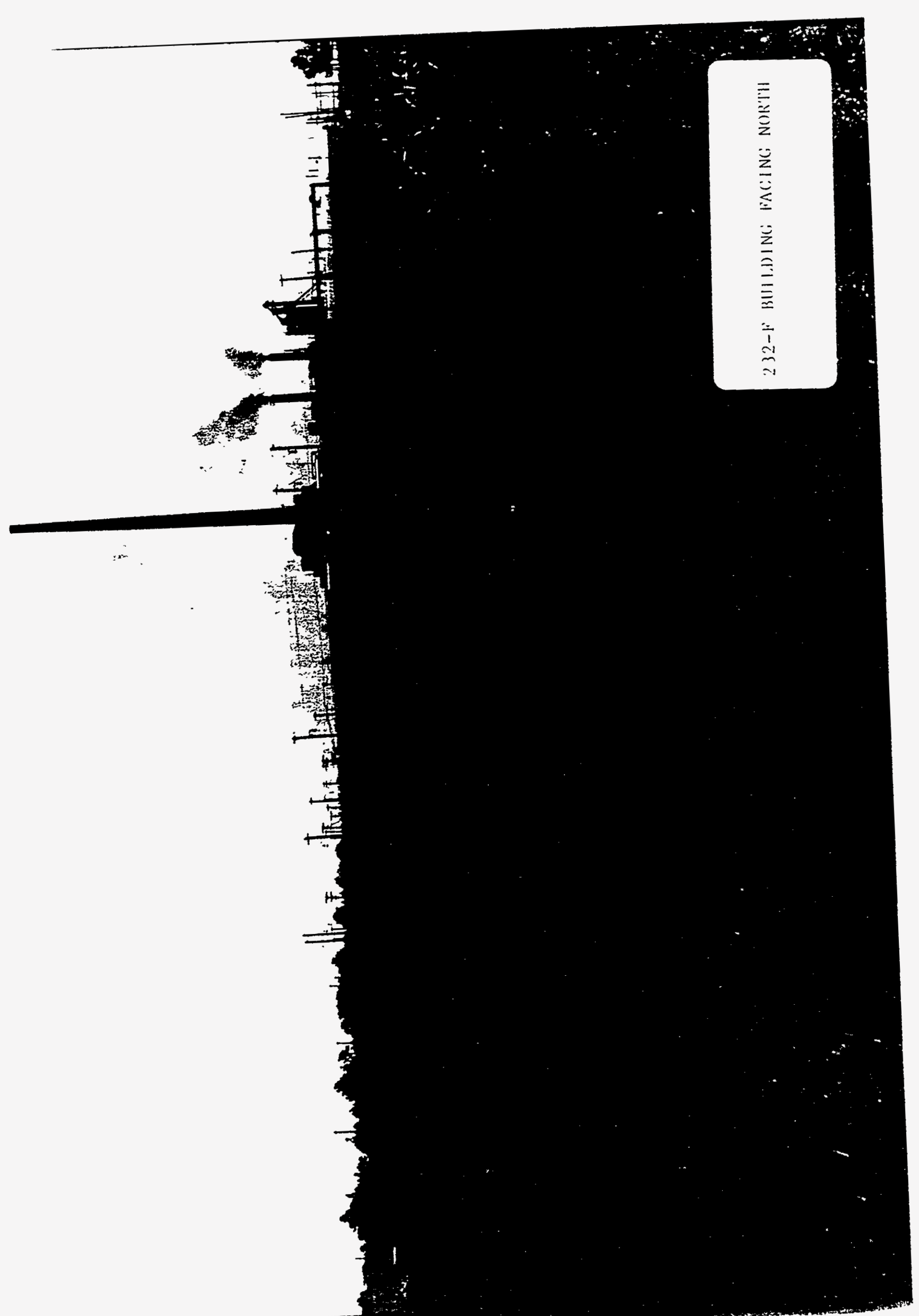




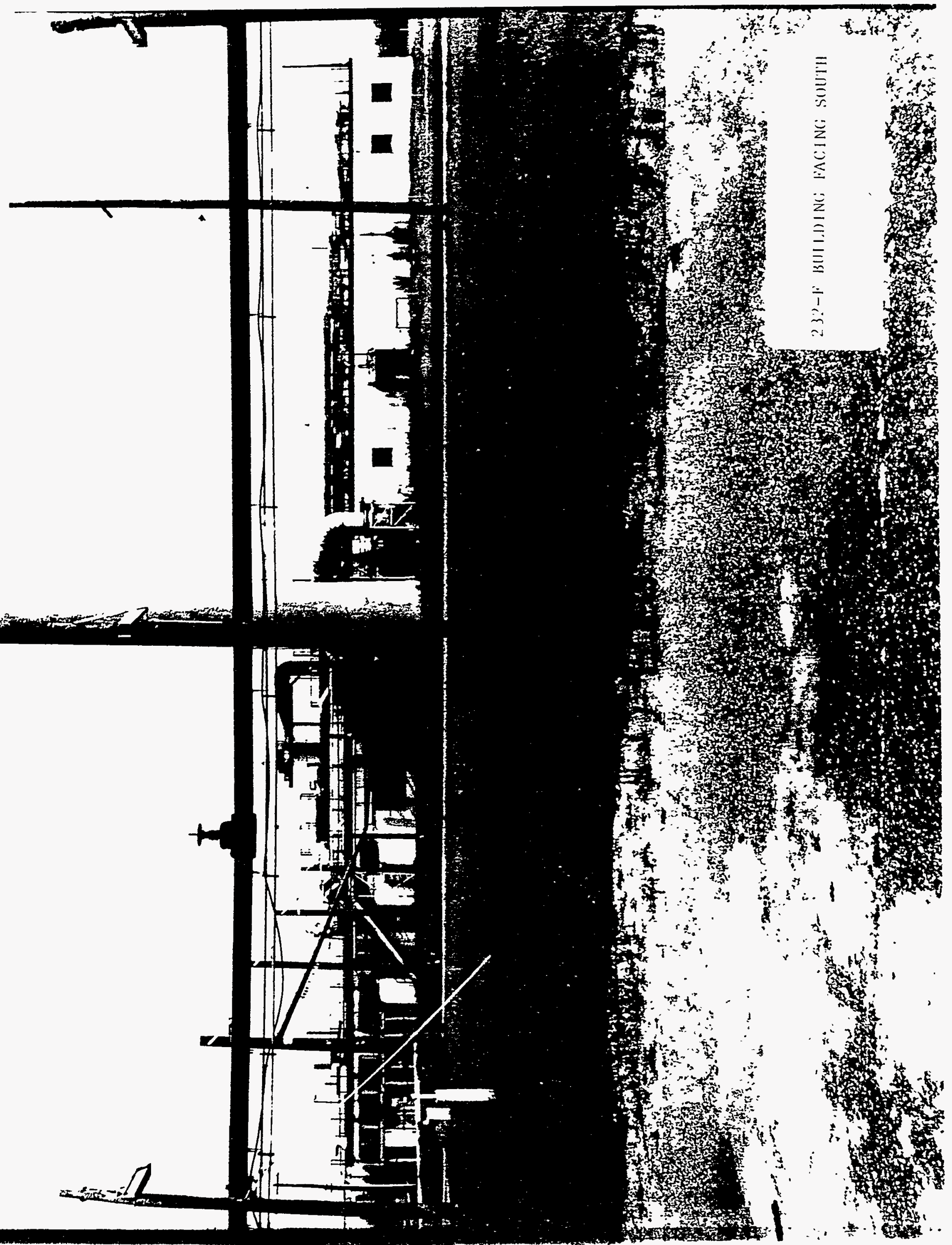




\section{$\Xi C:$ HL.IOS YวFIS $\unlhd-\succsim \varepsilon こ$}

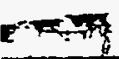

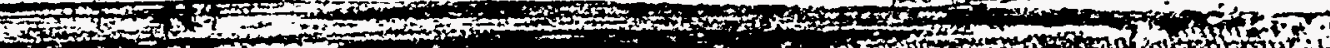

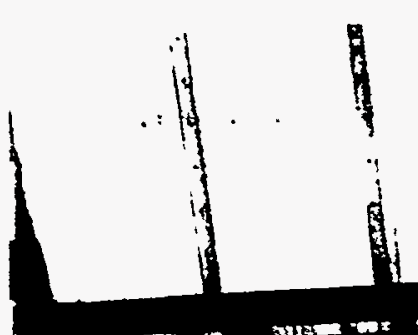

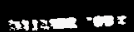

s.

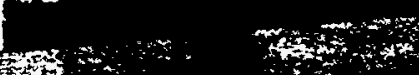

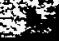

(N) 


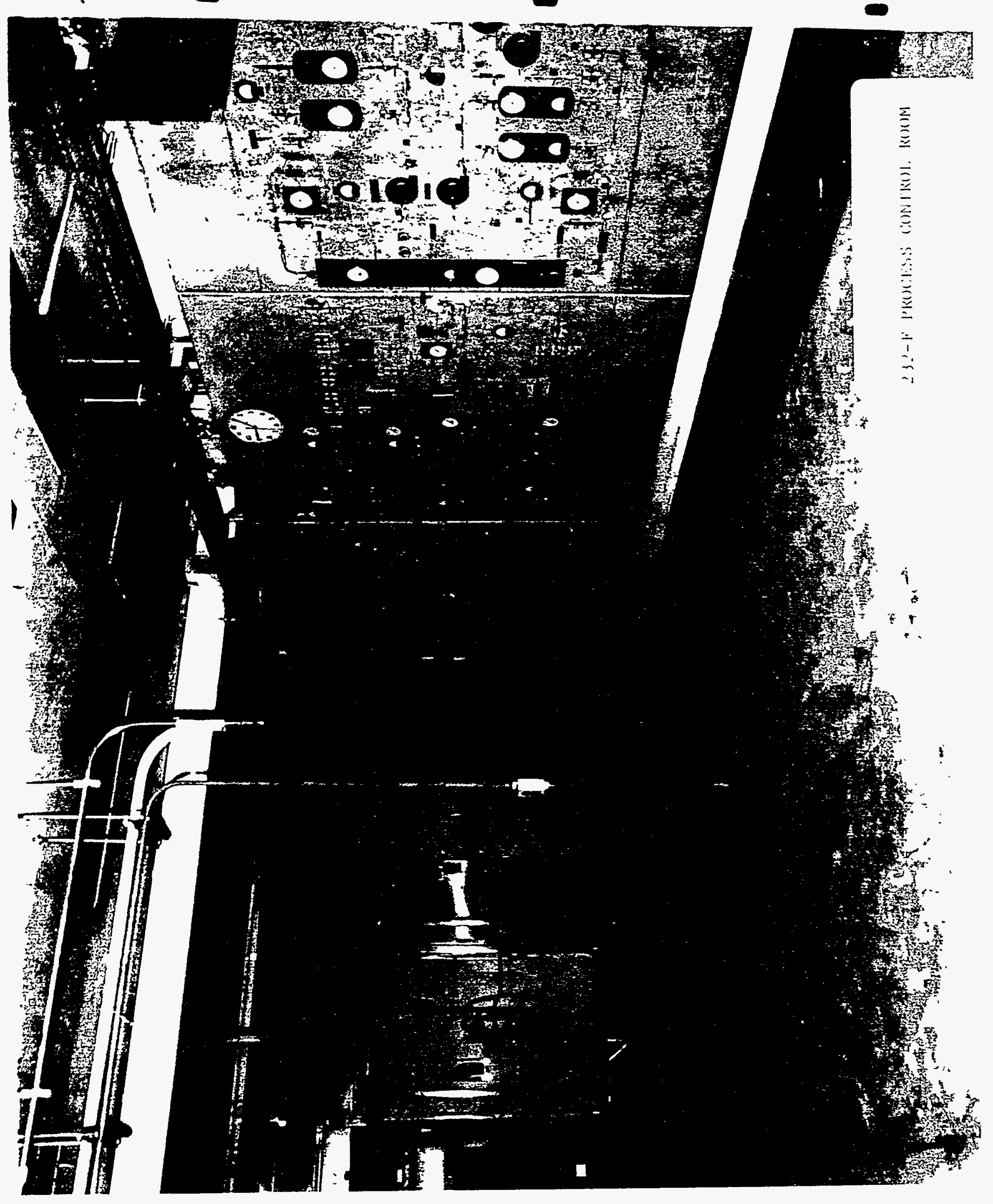


$-4+1+4$

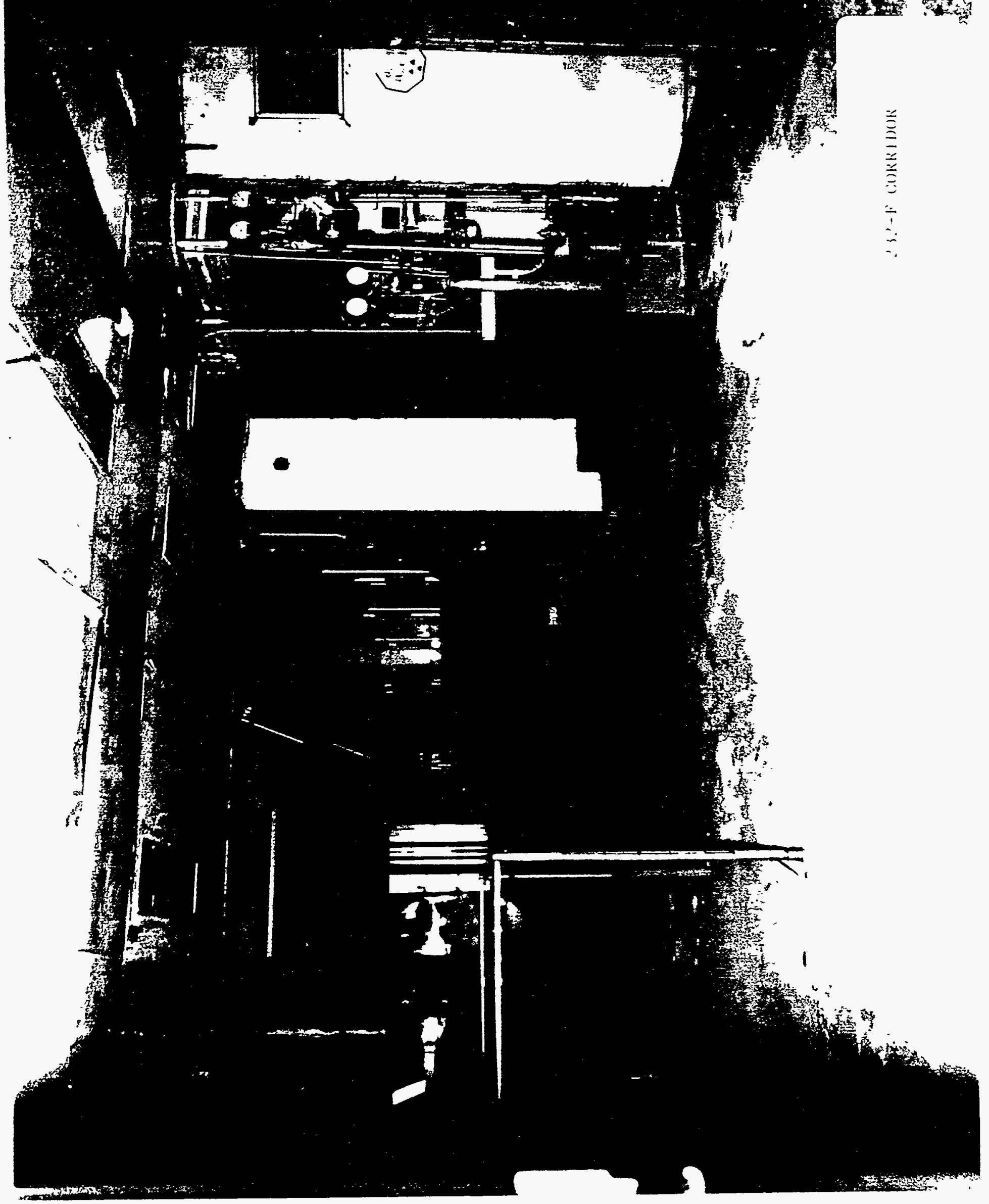


172

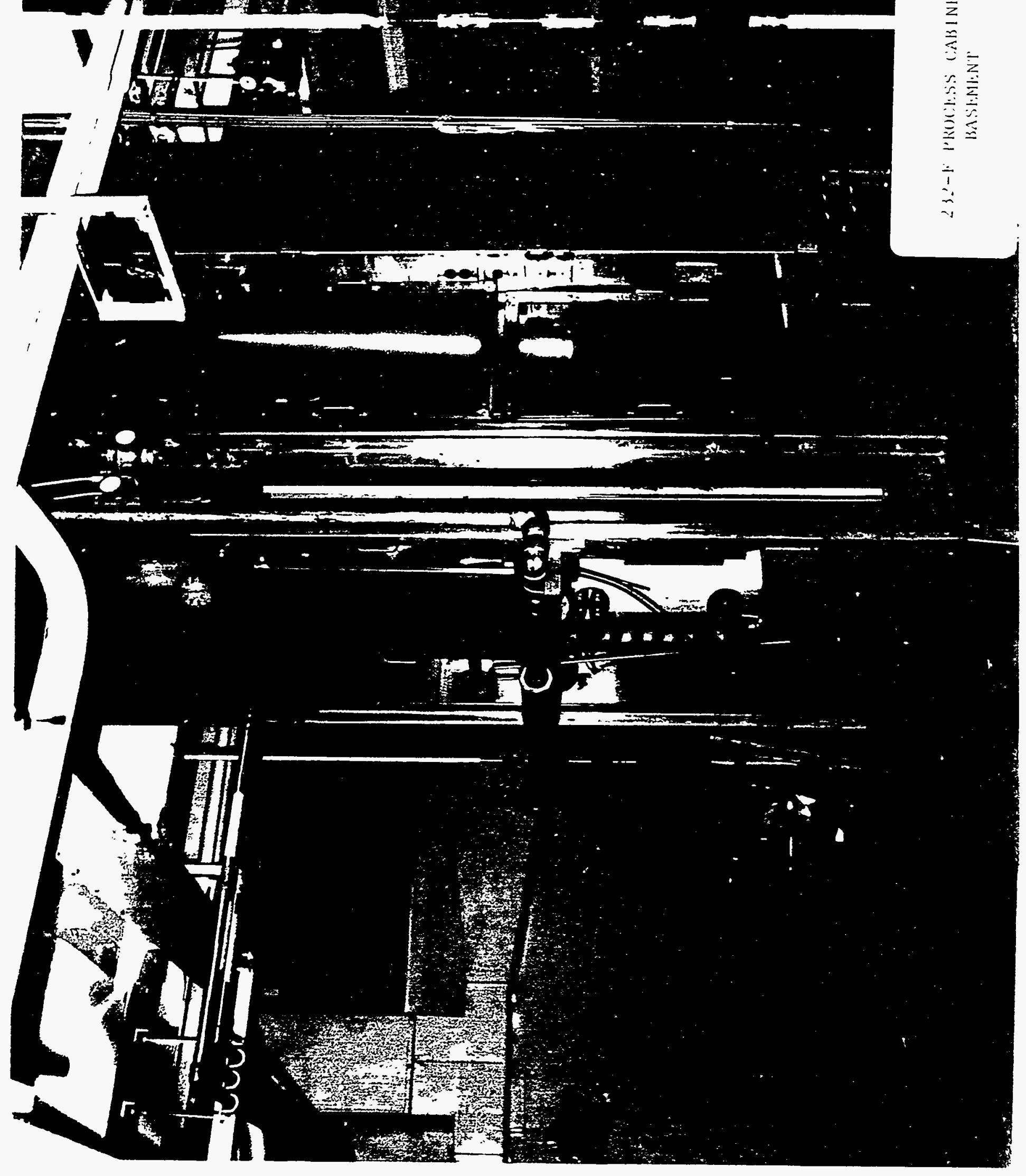




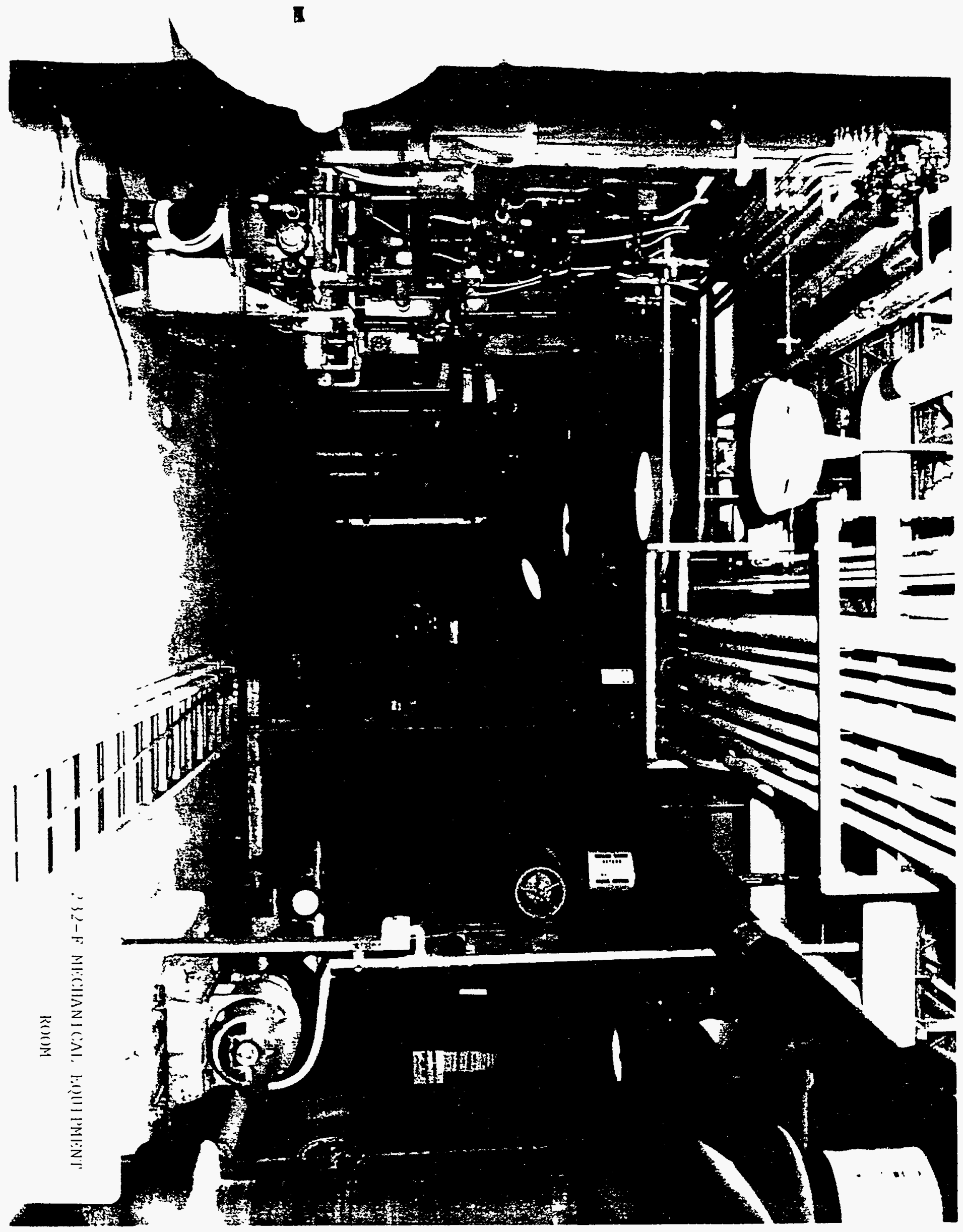




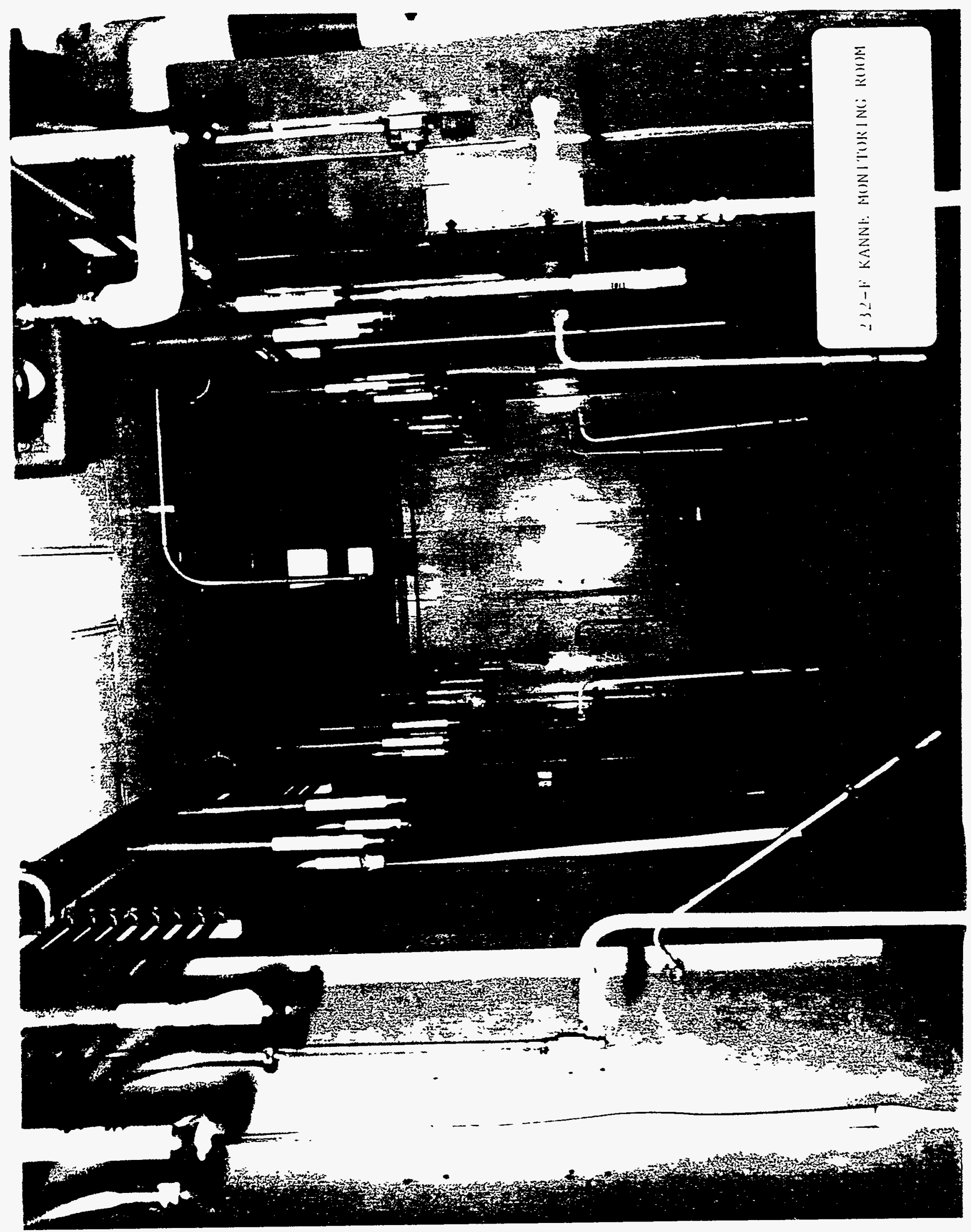




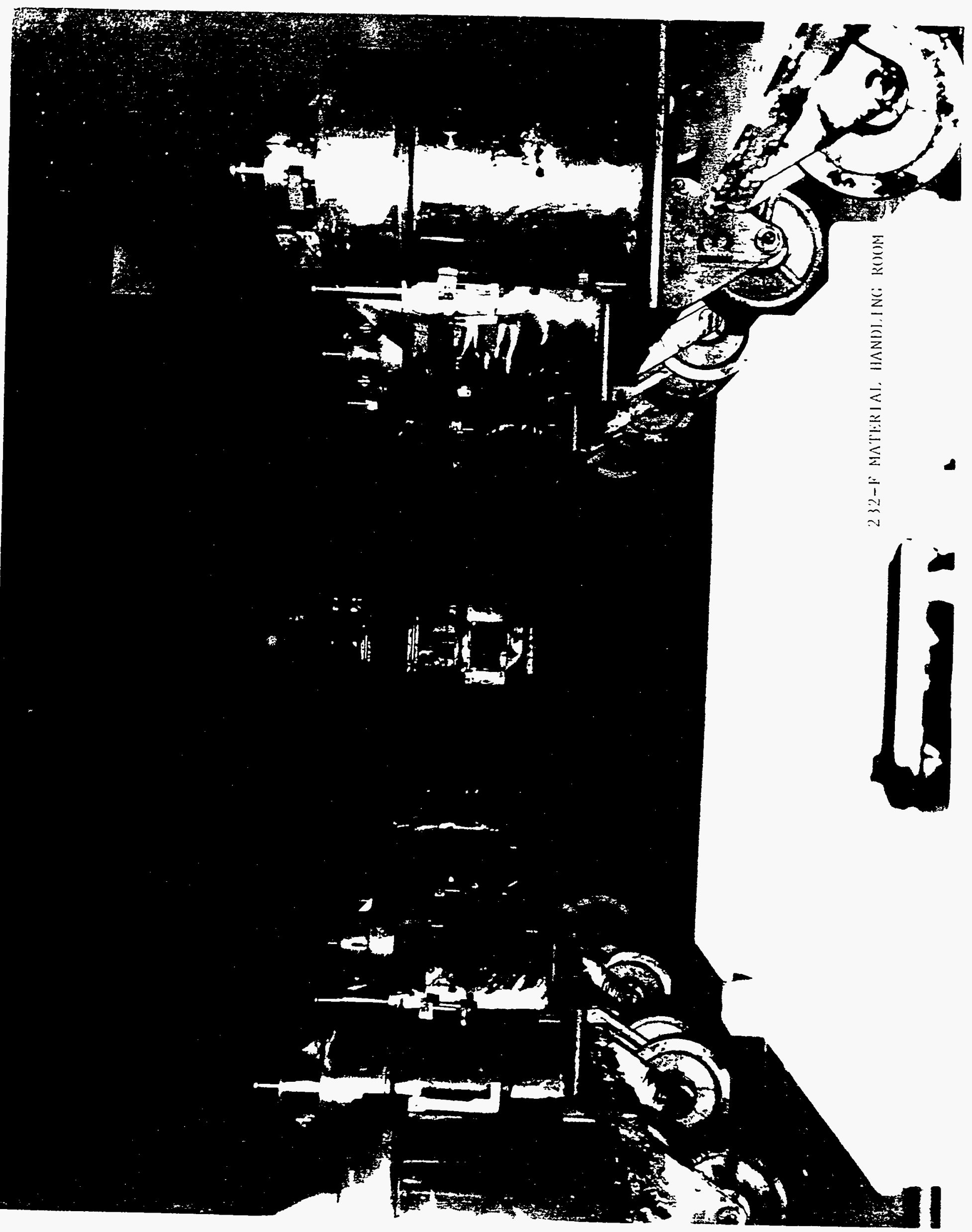




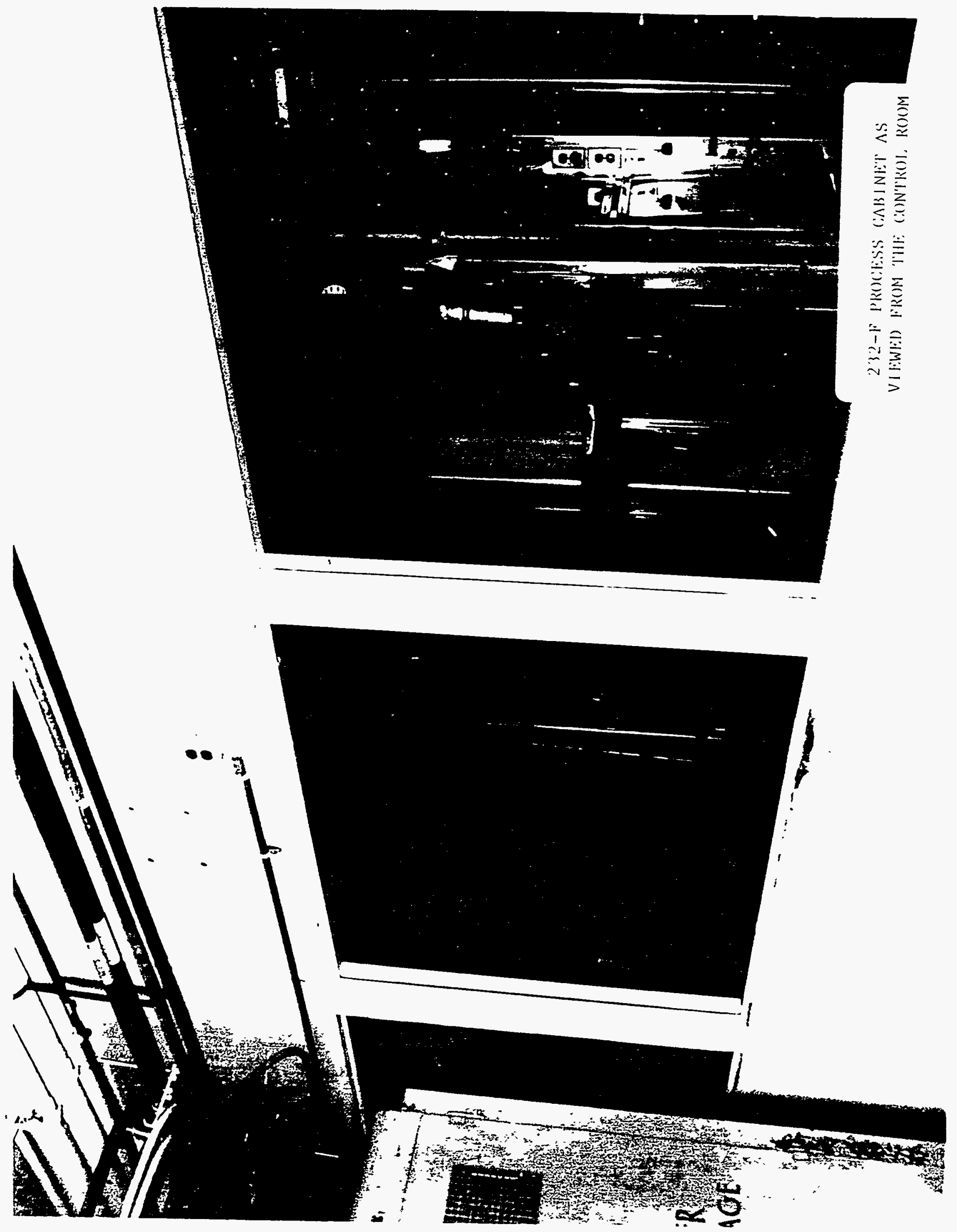




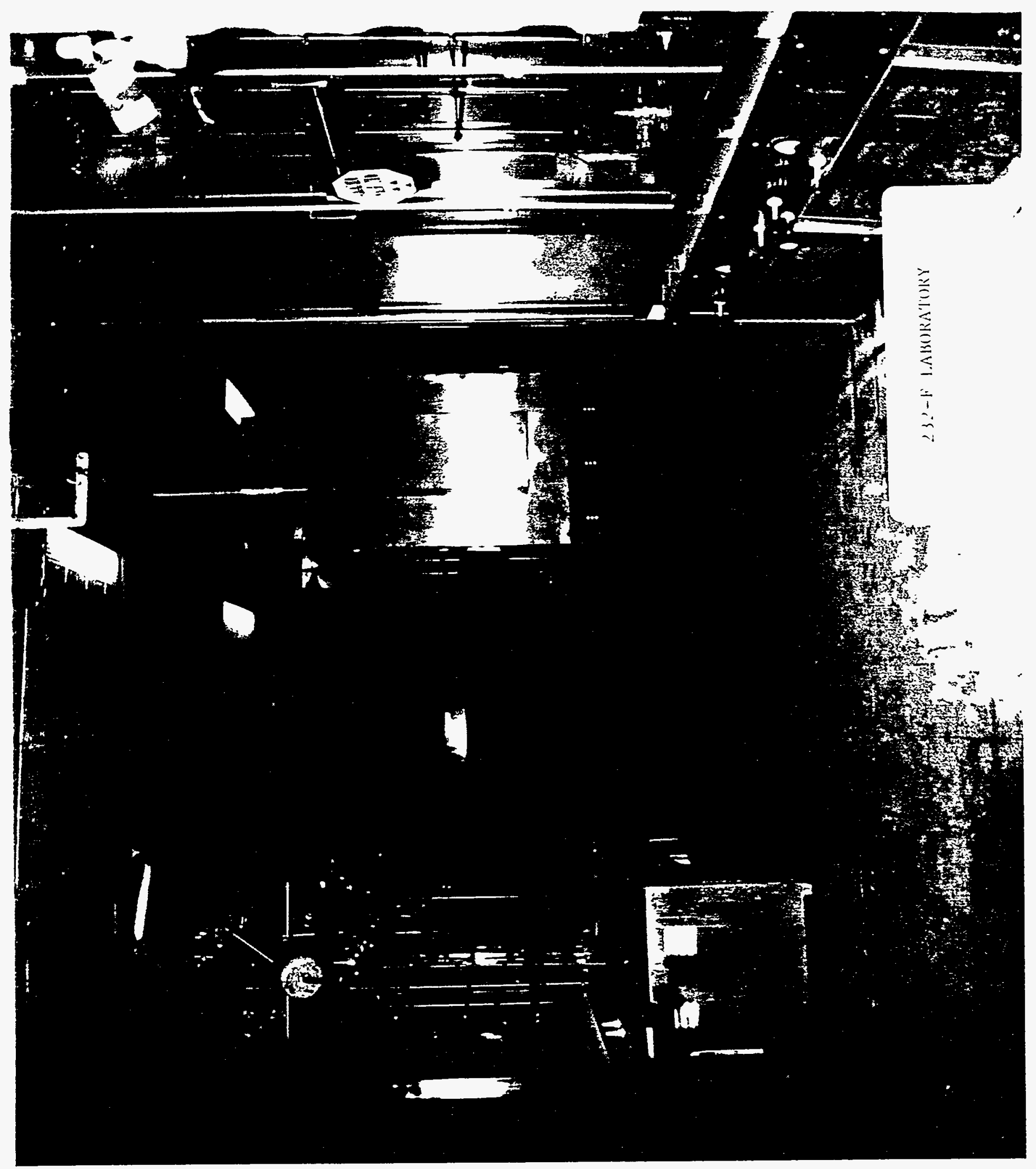

